\title{
PENERAPAN PENDEKATAN SAINTIFIK DALAM PEMBELAJARAN VOKAL
}

\author{
Surya Manggala Hutama ${ }^{l}$, Suharto ${ }^{2}$, \\ ${ }^{I}$ Mahasiswa Jurusan Sendratasik Universitas Negeri Semarang Indonesia \\ ${ }^{2}$ Dosen Jurusan Sendratasik Universitas Negeri Semarang Indonesia \\ Pendidikan Seni Musik, Universitas Negeri Semarang \\ Email: suryamanggalla@gmail.com
}

\begin{abstract}
Abstrak: Penelitian ini bertujuan untuk mengetahui, mendeskripsikan dan menyimpulkan bagaimana penerapan pendekatan saintifik dalam pembelajaran vokal pada siswa kelas VIII di SMP Negeri 2 Purwokerto. Penelitian ini dilakukan dengan metode kualitatif yaitu prosedur pemecahan masalah dilakukan dengan menganalisa, menggambarkan keadaan objek dengan menggunakan pendekatan musikologi dan kependidikan. Teknik mengambil data dengan teknik observasi, wawancara, dan studi dokumentasi. Teknik analisis data dilakukan melalui teknik reduksi data, penyajian data, dan penarikan kesimpulan. Hasil penelitian ini adalah sebagai berikut: proses pelaksanaan pembelajaran terdiri dari pendahuluan yang terdiri dari mengkondisikan suasana kelas, apersepsi, dan menyampaikan tujuan pembelajaran. Kegiatan inti terdiri dari tahapan saintifik yaitu tahapan mengamati, menanya, mengasosiasi, mencoba dan mengkomunikasikan. Kegiatan penutup meliputi membuat rangkuman atau simpulan pelajaran, melakukan penilaian atau refleksi, memberikan umpan balik terhadap proses dan hasil pembelajaran, merencanakan kegiatan tindak lanjut dan menyampaikan rencana pembelajaran pada pertemuan berikutnya. Kemudian evaluasi atau penilaian meliputi 3 aspek evaluasi yang dilakukan oleh pengetahuan, keterampilan, dan sikap.
\end{abstract}

Kata kunci: penerapan, pendekatan saintifik, pembelajaran vokal.

\section{PENDAHULUAN}

Pentingnya pendidikan seni di sekolah menjadi salah satu aspek yang diperhitungkan oleh pemerintah. Pendidikan seni dapat digunakan sebagai sarana untuk membantu menyiapkan anak untuk kreatif, inovatif, dan mempunyai kepekaan yang tinggi. Dengan seni kita belajar kreatif dan berbagai hal lain yang dapat mengasah kemampuan keterampilan kita. Seni merupakan suatu keindahan dan dalam paradigma pendidikan seni, terkandung pula tujuan pendidikan keseluruhannya, demikian juga hal itu berlaku untuk pendidikan seni musik. Tujuan seni musik adalah meningkatkan sensitivitas, kemampuan mengekspresikan diri dan kemampuan mengapresiasi keindahan dan harmoni. Kemampuan mengapresiasi dan mengekspresikan keindahan serta harmoni mencakup apresiasi dan ekspresi, baik dalam kehidupan individual maupun bersama sehingga mampu menikmati dan mensyukuri hidup. Dalam mensyukuri hidup ini, baik secara individu maupun dalam kehidupan kemasyarakatan, dengan menjadikan suatu kemampuan menciptakan kebersamaan yang harmonis.

Menyiapkan siswa yang kreatif, inovatif, dan mempunyai kepekaan tinggi dalam pendidikan seni musik, seorang guru harus memiliki ide yang kreatif dalam proses pembelajaran agar bisa tercapai tujuan pendidikan yang diinginkan. Pendidikan seni musik di sekolah dapat mengembangakan keterampilan siswa dalam menguasai bahasa musik yang dimulai sejak usia dini, aktivitas menyanyi dengan menggunakan lagu-lagu tradisional yang dikenal siswa, dan melibatkan musik dalam pelajaranpelajaran lain akan sangat membantu. Sesuai dengan tujuan kurikulum pendidikan kesenian di SMP, pembelajaran musik di sekolah sebaiknya melibatkan aktivitas-aktivitas beryanyi, memainkan instrumen, melatih kepekaan 
telinga (ear training), improvisasi, dan berkreasi (Wulandari, 2015:2).

Salah satu kompetensi dasar untuk siswa SMP di bidang seni musik adalah memahami teknik vokal dalam bernyanyi lagu secara vokal grup maupun solo. Bernyanyi merupakan kegiatan melantunkan suara melalui nada-nada yang menggunakan teknik-teknik tertentu. Untuk bisa melakukan kemampuan bernyanyi dengan baik, dalam setiap pembelajaran vokal di sekolah harus disesuaikan dengan kurikulum yang didalamnya terdapat pendekatan ada metode pembelajaran yang disesuaikan dengan tujuan pembelajaran yang diinginkan oleh guru seni budaya (seni musik). Menurut data observasi awal, SMP Negeri 2 Purwokerto menggunakan kurikulum 2013. Permendikbud Nomor 160 Tahun 2014 menyebutkan bahwa satuan pendidikan dasar dan pendidikan menengah yang telah melaksanakan Kurikulum 2013 sejak semester pertama pada Tahun Pelajaran 2014/2015 kembali melaksanakan Kurikulum Tahun 2006 mulai semester kedua selama Tahun Pelajaran 2014/2015 sampai ada ketetapan dari Kementerian untuk melaksanakan Kurikulum 2013 (Utami, 2015:2). Sedangkan satuan pendidikan dasar dan pendidikan menengah yang telah melaksanakan Kurikulum 2013 selama tiga semester tetap menggunakan Kurikulum 2013. Sekolah-sekolah tersebut merupakan sekolah rintisan penerapan Kurikulum 2013 dan SMP Negeri 2 Purwokerto merupakan salah satu dari sekolah rintisan penerapan kurikulum 2013.

Kurikulum 2013 mempunyai tujuan yang sesuai dengan tujuan pendidikan nasional, pengembangan peserta didik dilakukan secara bertahap sesuai dengan perkembangan psikologi peserta didik sehingga pendidikan pada tingkat sekolah dasar harus fokus pada pengembangan sikap dan perilaku. Maka dari itu, dalam penerapan kurikulum 2013 peserta didik diharapkan bukan hanya pandai dalam teori yang bersifat hafalan saja, tetapi peserta didik diharapkan memiliki kemampuan dalam menggunakan, mencari, dan menerapkan informasi dari lingkuangan secara logis, kritis, dan kreatif.

Menurut Lukman Ali, penerapan adalah mempraktekkan, memasangkan (Ali, 1995:1044). Penerapan juga bisa diartikan dengan kata implementasi. Implementasi diartikan sebagai pelaksanaan atau penerapan. Artinya yang dilaksanakan dan diterapkan adalah kurikulum yang telah dirancang / didesain untuk kemudian dijalankan sepenuhnya. Kurikulum merupakan program yang diberikan oleh suatu lembaga penyelenggara pendidikan yang berisi rancangan atau rumusan pelajaran yang akan diberikan kepada peserta didik dalam satu periode jenjang pendidikan. Penerapan kurikulum dituntut untuk melaksanakan sepenuhnya apa yang telah direncanakan.

Penerapan kurikulum 2013 pada pembelajaran vokal adalah pembelajaran yang berhubungan erat dengan pamahaman (kognitif), emosi (afektif), dan keterampilan (psikomotor). Dalam pelaksanaan pembelajaran musik di SMP Negeri 2 Purwokerto, setiap anak belajar aktif dengan mengikuti pelajaran dari guru dan guru harus bisa mengantarkan anak ke pintu gerbang penalaran. Maka dari itu guru harus terbangun dalam fajar pengetahuan dimana harus menguasai materi pembelajaran yang akan diajarkan kepada peserta didik.

Terdapat dua persoalan pokok dalam pembelajaran, yaitu masukan dan keluaran. Yang pertama adalah persoalan mengenai masukan, yaitu berkaitan dengan bagaimana proses belajar berlangsung dan prinsip-prinsip apa saja yang digunakan dalam proses pembelajaran. Dalam pembelajaran dibutuhkan pendekatan, pendekatan ini bisa berupa metode pembelajaan yang digunakan untuk mencapai tujuan pembelajaran yang diinginkan. Guru seni musik harus bisa 
menghilangkan kesalahpahaman yang ada pada persepsi siswa khususnya di SMP yang menganggap bahwa pelajaran seni musik merupakan pelajaran yang tidak penting atau hanya pelajaran pelengkap saja yang tidak mempengaruhi kenaikan kelas. Untuk mengatasi permasalahan tersebut, seorang guru harus bisa memilih pendekatan dan metode pembelajaran yang tepat agar siswa bisa menyukai pelajaran seni musik dan bisa mencapai tujuan pembelajaran yang diinginkan. Dalam proses pembelajaran teknik vokal, yang perlu diperhatikan adalah bagaimana meningkatkan pemahaman siswa mengenai teknik vokal agar siswa termotivasi atau mempunyai keinginan yang timbul dari dalam diri siswa tersebut.

Permasalahan yang kedua adalah keluaran, yaitu mengenai hasil belajar. Dalam melaksanakan pembelajaran, seorang guru pasti mempunyai tujuan yang sudah disusun pada perencanaan pembelajaran. Evaluasi berhubungan dengan tercapainya tujuan pembelajaran yang diinginkan oleh guru yang dapat diketahui melalui evaluasi. Evaluasi peserta didik dilakukan oleh guru dengan cara menilai hasil belajar di akhir pembelajaran.

Pendekatan saintifik berkaitan erat dengan metode saintifik. Metode saintifik (ilmiah) pada umumnya melibatkan kegiatan pengamatan atau observasi yang dibutuhkan untuk perumusan hipotesis atau mengumpulkan data (Sani, 2014:50). Dalam proses ilmiah, siswa mengkonstruk pengetahuan dengan menanya, melakukan pengamatan, melakukan pengukuran, mengumpulkan data, mengorganisir dan menafsirkan data, memperkirakan hasil, melakukan eksperimen, menyimpulkan dan mengkomunikasikan (Martin, 2006: 67). Pembelajaran musik di SMP Negeri 2 Purwokerto menggunakan pendekatan saintifik. Pembelajaran dengan menggunakan pendekatan saintifik tidak hanya memperhatikan aspek kognitif saja, tetapi afektif dan keterampilan juga. Berdasarkan teori Dyer (Sani 2014: 53), pendekatan saintifik (scientific approach) dalam pembelajaran memiliki komponen proses belajar antara lain: 1) mengamati; 2) menanya; 3) mencoba/mengumpulkan informasi; 4) menalar/asosiasi, membentuk jejaring (melakukan komunikasi).

Berkaitan hal tersebut maka dilakukan penelitian yang bertujuan untuk mengetahui dan mendeskripsikan penerapan pendekatan saintifik dalam pembelajaran vokal pada siswa kelas VIII di SMP Negeri 2 Purwokerto.

\section{METODE PENELITIAN}

Suatu penelitian harus memperhatikan metode yang digunakan dalam rangka mencapai tujuan suatu penelitian. Peneltian ini menggunakan pendekatan musikologi dan kependidikan. dengan metode penelitian kualitatif. Musikologi mempelajari musik kepada ahli. Dalam penelitian ini penulis melakukan penelitian mengenai teknik vokal dalam bernyanyi kepada guru musik di SMP Negeri 2 Purwokerto. Pendekatan kependidikan menekankan pengembangan potensi peserta didik. Peneliti meneliti bagaimana proses pembelajaran teknik vokal dan perkembangan kemampuan vokal siswa di SMP Negeri 2 Purwokerto. Metode yang digunakan adalah metode penelitian kualitatif karena peneliti ingin mendeskripsikan suatu fenomena sesuai dengan keadaan yang sebenarnya dan menyajikannya dalam bentuk kata-kata. Alasan lain peneliti menggunakan jenis penelitian ini adalah karena peneliti ingin melakukan penelitian pada kondisi yang alamiah berdasarkan hasil pengumpulan data observasi, wawancara, dan studi dokumentasi, dengan peneliti sebagai instrumen kunci.

Metode penelitian kualitatif sering disebut metode penelitian naturalistik karena penelitiannya dilakukan pada kondisi yang alamiah. Penelitian dilakukan pada obyek yang alamiah. Obyek yang alamiah adalah obyek yang berkembang apa adanya, tidak dimanipulasi oleh 
peneliti dan kehadiran peneliti tidak begitu mempengaruhi dinamika pada obyek tersebut. Metode penelitian kualitatif menurut Sugiyono (2013:15) adalah metode penelitian yang berdasarkan filsafat postpositivisme, digunakan untuk meneliti pada obyek yang alamiah, (sebagai lawannya adalah eksperimen) dimana peneliti adalah sebagai instrument kunci, pengambilan sampel sumber data dilakukan secara purposive dan snowball, teknik pengumpulan dengan trianggulasi (gabungan), analisis data bersifat induktif/ kualitatif, dan hasil penelitian kualitatif lebih menekankan makna dari pada generalisasi.

Peneliti menggunakan jenis penelitian deskriptif kualitatif karena peneliti ingin mendeskripsikan bagaimana penerapan pendekan saintifik dalam pembelajaran vokal pada siswa kelas VIII di SMP Negeri 2 Purwokerto. Dalam hal ini yang akan diteliti adalah pendekatan saintifik yang diterapkan pada pembelajaran teknik musik di SMP Negeri 2 Purwokerto.

Penelitian ini dilakukan di SMP Negeri 2 Purwokerto yang berlokasi di Jalan Gereja No. 20 Sokanegara, Purwokerto Timur, Banyumas. Sasaran dari penelitian ini adalah penerapan pendekatan Saintifik pada pembelajaran musik di SMP Negeri 2 Purwokerto, meliputi data siswa, perencanaan pembelajaran, pelaksanaan pembelajaran, evaluasi pembelajaran, hasil pembelajaran.

Data atau informasi yang diperlukan diambil dengan menentukan sumber data atau informasi yang terdiri dari subjek data dan objek data. Subjek data dari penelitian ini adalah guru seni budaya (seni musik) dan beberapa siswa SMP Negeri 2 Purwokerto. Hal ini dikarenakan guru dan siswa merupakan pihak yang terlibat/mengalami langsung dan saling mendukung terlaksananya proses pembelajaran dan agar hasil belajar siswa bisa baik dengan menggunakan pendekatan saintifik pada pembelajaran musik di SMP Negeri 2 Purwokerto.
Objek data dari penelitian ini adalah informasi yang diperoleh dari subjek penelitian. Objek penelitian ini adalah kegiatan-kegiatan yang merupakan bentuk dari penerapan pendekatan saintifik pada pembelajaran musik di SMP Negeri 2 Purwokerto serta berbagai bentuk dukungan yang diberikan untuk memperlancar proses pembelajaran tersebut.

Adapun teknik penelitian pada penelitian ini yaitu: (1) Observasi yaitu suatu proses yang kompleks, suatu proses yang tersusun dari pelbagai proses biologis dan psikologis, dua diantara yang terpenting adalah proses pengamatan dan ingatan. Hal-hal yang akan diobservasi dalam penelitian adalah siswa SMP Negeri 2 Purwokerto yang mendapatkan materi seni musik, kemudian materi ajar dan proses pembelajaran seni musik yang diberikan guru kepada siswa SMP Negeri 2 Purwokerto. (2) Wawancara menurut Maleong (dalam Sumaryanto, 2014:39) adalah percakapan dengan maksud tertentu. Percakapan tersebut dilakukan oleh dua pihak, yaitu antara pewawancara yang memberikan pertanyaan dan yang diwawancarai yang menjawab pertanyaan. Narasumber dalam penelitian ini adalah guru seni budaya (seni musik) dan siswa kelas VIII SMP Negeri 2 Purwokerto. Materi dari wawancara ini adalah bagaimana proses pembelajaran musik terlaksana di SMP Negeri 2 Purwokerto. (3) studi dokumentasi dalam penelitian ini dilakukan untuk memperoleh data mengenai perencanaan pembelajaran dan proses pelaksanaan pembelajaran musik di SMP Negeri 2 Purwokerto. Studi dokumentasi mengenai pelaksanaan pembelajaran bertujuan untuk memperoleh dokumen berupa gambar-gambar saat berlangsungnya proses pembelajaran. Selain data mengenai proses pembelajaran, data mengenai lokasi sekolah, jumblah guru, dan jumlah siswa juga diambil pada studi dokumentasi ini.

Metode pemeriksaan keabsahan data dilakukan dengan triangulasi Triangulasi 
dilakukan dengan tiga cara, yaitu: (1) Triangulasi sumber adalah keabsahan data dengan mengacu beberapa sumber merupakan pengecekan derajad data yang diperoleh berdasarkan fakta di lapangan, (2) Triangulasi teknik untuk menguji kredibilitas data dilakukan dengan cara mengecek data kepada sumber yang sama dengan teknik yang berbeda, (3) triangulasi waktu untuk menguji kredibilitas data dilakukan dengan cara melakukan pengecekan dengan wawancara, observasi atau teknik lain dalam waktu dan situasi yang berbeda.

Teknik analisis data dilakukan dengan reduksi data, penyajian data, dan menarik kesimpulan. Mereduksi data adalah berarti merangkum, memilih hal-hal yang pokok, memfokuskan pada hal-hal yang penting, dicari tema dan polanya dan membuang yang tidak perlu (Sugiyono, 2013:338). Dalam penelitian kualitatif penyajian data dapat dilakukan dalam bentuk uraian singkat, bagan dan hubungan antar kategori, flowchart dan sejenisnya. Dengan penyajian data, maka data terorganisasikan, tersusun dalam pola hubungan, sehinggan akan mudah dipahami. Kesimpulan dalam penelitian kualitatif yang diharapkan adalah merupakan temuan baru yang sebelumnya belum pernah ada

\section{HASIL PENELITIAN DAN PEM- BAHASAN}

\section{Hasil Penelitian}

Guru seni musik di SMP Negeri 2 Purwokerto menggunakan pendekatan saintifik dalam pembelajaran musik. Pendekatan saintifik memiliki peran yang cukup besar pada pembelajaran musik di sekolah. Pendekatan saintifik memiliki prosedur atau langkah-langkah ilmiah yang diterapkan dalam pembelajaran, hal ini bisa membuat siswa semakin mandiri dalam pembelajaran dan mampu membuat kreatifitas siswa dalam pembelajaran meningkat. Tujuan dari pembelajaran tidak hanya menjadikan siswa berkambang dalam aspek kognitif saja, melainkan juga berkembang dalam aspek afektif dan psikomotorik. Dalam pembelajaran musik siswa mengembangkan pengetahuan, kemampuan bersosialisasi, dan keterampilan dalam menyanyikan lagu secara unisono maupun grup vokal, kemudian keterampilan dalam memainkan alat musik tradisional dan alat musik sekolah.

Pembelajaran dengan menggunakan pendekatan saintifik tidak hanya mengembangakan aspek kognitif, afektif, dan psikomotor saja, kualitas lain yang dikembangkan dan harus terealisasikan dalam proses pembelajaran antara lain kreativitas, kemandirian, kerja sama, solidaritas, kepemimpinan, empati, toleransi dan kecakapan hidup peserta didik guna membentuk watak yang baik. Untuk mencapai kualitas dalam kegiatan pembelajaran perlu menggunakan prinsip yang sesuai dengan pendekatan saintifik yaitu (1) pembelajaran berpusat pada peserta didik, (2) mengembangkan kreativitas peserta didik, (3) menciptakan kondisi menyenangkan dan menantang, (4) bermuatan nilai etika, estetika, logika, dan kinestetika, dan (5) menyediakan pengalaman belajar (learning experience) yang beragam melalui peneapan berbagai strategi dan metode pembelajaran yang menyenangkan, kontekstual, efektif, efisien, dan bermakna.

Metode pembelajaran yang digunakan oleh guru seni budaya SMP Negeri 2 Purwokerto ada berbagai macam karena dalam penerapan pendekatan saintifik hampir semua metode pembelajaran yang ada dapat diterapkan. Dalam penerapan pendekatan saintifik, metode pembelajaran sudah disusun secara terstruktur tahapannya sesuai dengan pendekatan ilmiah dalam pembelajaran.

Pengertian discovery learning menurut Jerome Bruner (dalam Hosnan, 2014:281) adalah metode belajar yang mendorong siswa untuk mengajukan pertanyaan dan menarik kesimpulan dari 
prinsip-prinsip umum praktis contoh pengalaman. Dalam penerapannya, siswa mendapat pelajaran tentang karawitan atau alat musik gamelan, kemudian siswa diberi tugas oleh guru untuk mencari nama-nama alat musik yang terdapat dalam gamelan dan apa saja ciri khasnya. Selanjutnya problem based learning merupakan pembelajaran melalui permasalahan sehingga siswa dapat menyusun pengetahuannya sendiri dan mengembangkan keterampilan yang lebih tinggi. Sebagai contoh yang dilakukan guru adalah memberikan masalah nyata yang ada mengenai kebudayaan di Indonesia kemudian siswa diberi tugas mengapa masalah tersebut dapat terjadi. Yang ketiga adalah project based learning adalah pembelajaran dengan proyek atau tugas yang biasanya dilaksanakan selama pembelajaran dan hasilnya dikomunikasikan pada akhir pertemuan. Pada model pembelajaran ini guru selalu membimbing untuk membuat proyek yang bisa dipertanggungjawabkan. Ketiga model diatas merupakan model pembelajaran yang digunakan oleh guru guna mencapai tujuan pembelajaran dan peningkatan kualitas peserta didik. Maka dari itu sesuai dengan pendekatan saintifik, terdapat lima tahapan pembelajaran dalam pendekatan saintifik yaitu mengamati, menanya, mengasosiasi, mencoba, dan mengkomunikasikan

Pendekatan saintifik dalam pembelajaran musik terbagi menjadi 5 tahapan yaitu (1) mengamati dengan cara siswa melihat dan memperhatikan video yang diberikan guru dan memperhatikan contoh bernyanyi yang dilakukan guru, (2) menanya mengenai materi vokal yang telah diberikan guru, (3) mengasosiasi atau menalar informasi yang telah didapatkan siswa dari video dan materi yang diberikan oleh guru, (4) mencoba kegiatan bernyanyi sesuai dengan hasil pembelajarannya, (5) mengkomunikasikan atau menyajikan hasil pembelajaran vokal. Pelaksanaan pembelajaran musik di SMP Negeri 2 Purwokerto meliputi tahapan pendahuluan, kegiatan inti yang dalam pelaksanaannya sesuai dengan tahapan pendekatan saintifik yaitu mengamati, menanya, mengasosiasi, mencoba, dan mengkomunikasikan/ menyaji, kemudian yang terakhir adalah penutup. Kegiatan penutup meliputi kegiatan evaluasi yang dilakukan untuk mengetahui sampai mana pemahaman yang siswa dapat mengenai pembelajaran yang sudah diberikan oleh guru. Dalam penerapannya, tahapan dalam pendekatan saintifik lebih menonjo diterapkan pada kegiatan inti pembelajaran. Kemudian dalam setiap pertemuan tidak semua tahapan dilakukan oleh guru dikarenakan guru ingin pembelajaran vokal yang didapat siswa sesuai dengan apa yang diinginkan guru yaitu bertahap dari teori kemudian praktek.

\section{Pembahasan}

Kegiatan pendahuluan yang dilakukan oleh guru sesuai dengan RPP yang telah dibuat antara lain guru mengkondisikan susasana belajar dengan saling memberi salam dan berdoa, kemudian apersepsi sebagai pengantar materi pemberian motivasi oleh guru sebelum masuk ke kegiatan inti pembelajaran, dan menyampaikan tujuan pembelajaran. Kegiatan pendahuluan bertujuan untuk menciptakan suasana awal pembelajaran yang efektif dan menyenangkan yang memungkinkan siswa dapat mengikuti pembelajaran dengan baik (Hosnan, 2014: 142). Pengkondisian suasana pembelajaran atau pengkondisian yang pertama dilakukan adalah saling memberi salam baik dari siswa maupun dari guru. Hal ini dilakukan agar hubungan antara guru baik dan ada rasa saling menghormati. Kemudian berdoa sebagai pengantar pembelajaran agar dalam berlangsungnya pembelajaran lancar dari awal hingga akhir pembelajaran. Setelah berdoa guru mempresensi kehadiran siswa guna kelengkapan administrasi sekolah supaya mengetahui siapa yang tidak berangkat beserta alasannya. 
Pengajaran apersepsi adalah menghubungkan pelajaran lama dengan pelajaran baru sebagai batu loncatan sehingga dengan mudah menyerap pelajaran baru (Fauzziyah, 2012: 2). Secara sederhana apersepsi bisa diartikan sebagai suatu proses menghubungkan pengetahuan lama dengan pengetahuan yang baru. Menurut Nurhasnawati (2004: 14) apersepsi bertujuan untuk membentuk pemahaman. Dalam penerapannya, guru melakukan kegiatan apersepsi untuk membentuk pemahaman siswa mengenai teknik vokal dan gaya lagu daerah melalui contoh dari guru yang dikaitkan dengan materi pada semester 1 yaitu bernyanyi lagu daerah secara vokal grup unisono. Guru juga selalu menjelaskan apa tujuan pembelajaran pada awal pertemuan kepada siswa karena dapat memberi gambaran akan materi yang dicapai selama pembelajaran. Tujuan pembelajaran diartikan sebagai suatu upaya pendidik atau guru dalam hubungan dengan tugastugasnya membina pesrta didik seperti meningkatkan kemampuan baca siswa, melatih keterampilan tangan siswa, atau menumbuhkan sikap disiplin dan percaya diri dikalangan siswa (Sagala, 2013: 155). Tujuan pembelajaran berkaitan dengan pembelajaran teknik dan gaya bernyanyi daerah secara vokal grup non unisono. tujuan tersebut antara lain (1) menerima, menanggapi, dan mengahargai keragaman dan keunikan musik di Indonesia sebagai anugerah Tuhan dengan baik, (2) menunjukan sikap menghargai, jujur, dan disiplin melaluiaktivitas berkesinian, (3) menunjukan sikap percaya dirimotivasi internal dan kepedulian terhadap lingkungan dalam berkarya seni, (4) memahami pengertian vokal grup, dan (5) mengidentifikasikan teknik bernyanyi dalam bentuk vokal grup.

Berdasarkan hasil observasi dan dokumentasi, guru lebih menonjolkan tahapan pendekatan saintifik pada kegiatan inti meliputi kegiatan mengamati, menanya, mengasosiasi, mencoba dan mengkomunikasikan.Penulis memulai penelitian pada pertemuan kedua dan tahapan mengamati yang dilakukan yaitu siswa memperhatikan guru mencontohkan teknik vokal dalam bentuk pemanasan. Pengamatan atau observasi adalah menggunakan panca indera untuk memperoleh informasi (Sani, 2014: 54). Siswa mendapatkan materi lagu daerah yang dinyanyikan secara vokal grup yaitu menyanyikan lagu daerah "Gundul-Gundul Pacul”. Sebelum menyanyikan lagu Gundul-Gundul Pacul, guru mengulang materi vokal yang pada semester sebelumnya sudah dipelajari. Kemudian guru memberikan contoh teknik-teknik dalam bernyanyi melalui pemanasan. Disini siswa menyimak dan memperhatikan bagaimana teknik vokal yang benar dalam menyanyikan lagu daerah yang dibawakan secaran vokal grup non unisono. Hal ini dilakukan agar siswa semakin tertarik mengamati. Tahapan ini memancing keingintahuan siswa akan teknik vokal yang benar dan juga sebagai alat agar siswa dapat termotivasi untuk bisa menyanyikan lagu daerah secara vokal grup dengan teknik vokal yang benar.

Dalam kegiatan bertanya, kompetensi yang dikembangkan adalah kreativitas, rasa ingin tahu, kemampuan merumuskan pertanyaan untuk membentuk pikiran kritis yang perlu untuk hidup cerdas dan belajar sepanjang hayat (Daryanto, 2014: 65). Kegiatan bertanya dilakukan dengan guru membimbing siswa dengan cara memberikan contoh tentang vokal grup yang menyanyikan lagu daerah. Yang diperhatikan siswa adalah cara menyanyikan lagu daerah dengan baik dan bagaimana teknik vokal yang baik. Contoh yang diberikan oleh guru merupakan media untuk memancing pertanyaan dalam diri siswa tentang vokal. Kegiatan mengasosiasi merupakan kelanjutan dari kegiatan menanya. Kegiatan "mengasosiasi/ mengolah informasi/ menalar" dalam kegiatan pembelajaran sebagaimana disampaikan dalam Permendikbud Nomor 81a Tahun 2013, 
adalah memproses informasi yang sudah dikumpulkan baik terbatas dari hasil kegiatan mengumpulkan/ eksperimen maupun hasil dari kegiatan mengamati dan kegiatan mengumpulkan informasi (Daryanto, 2014: 70). Ada beberapa tahapan dalam menalar. Yang pertama ialah membagi siswa ke dalam beberapa kelompok. Guru membagi menjadi 5 kelompok yang setiap kelompoknya terdiri dari 5-6 siswa. Bahasan yang akan didiskusikan siswa adalah jenis-jenis lagu daerah, unsur notasi angka, contoh lagu daerah dalam notasi angka, dan teknik dalam bernyanyi.

Tahap mencoba dalam pembelajaran gaya lagu daerah ini siswa diminta untuk menyanyikan lagu daerah secara vokal grup non unisono dengan menggunakan teknik vokal yang baik dan benar. Menurut Djamarah (dalam Hosnan, 2014: 58), metode eksperimen adalah cara penyajian pelajaran di mana siswa melakukan percobaan dengan mengalami dan membuktikan sendiri sesuatu yang dipelajari. Dalam pelaksanaannya, siswa belajar tahap demi tahap, maka dari itu guru membagi materi pembelajaran vokal grup ini menjadi 4 kali pertemuan. Tahapan mencoba ini dibagi menjadi 4 pertemuan oleh guru karena tidak bisa dijadikan 1 kali pertemuan untuk mendapatkan hasil pembelajaran. Peneliti memulai penelitian pada pertemuan kedua. Pada pertemuan pertama, sesuai dengan wawancara dengan guru seni musik di SMP Negeri 2 Purwokerto. Kegiatan bernyanyi dimulai pada pertemuan kedua, siswa mencoba untuk melakukan teknik bernyanyi melalui pemanasan yang dibimbing oleh guru. Guru mempraktekan teknik bernyanyi dalam bentuk pemanasan untuk melatih vokal siswa. Teknik vokal tersebut antara lain sikap badan, pernafasan, intonasi, artikulasi, dan frasering. Pemanasan dilakukan dengan sikap badan tegak dan menyanyikan notasi yang di bunyikan oleh guru melalui media keyboard. Setelah pemanasan dilakukan, siswa mulai menyanyikan lagu GundulGundul Pacul secara bersama-sama.

Pertemuan ketiga dilakukan siswa untuk berlatih materi lagu yang sudah diberikan oleh guru pada pertemuan kedua dan juga presentasi hasil diskusi. Selain itu pertemuan ketiga ini juga digunakan untuk membimbing siswa yang masih kebingungan bagaimana membagi suara. Setiap kelompok diminta untuk maju mencoba bagaimana hasil kreasi nya dalam lagu Gundul-Gundul Pacul. Pertemuan keempat digunakan untuk berlatih kembali mengulang lagu yang sudah dipelajari pada pertemuan ketiga. Tujuannya adalah supaya siswa bisa lebih siap bersama kelompoknya untuk penilaian yang akan diadakan oleh guru. Karena pada akhir materi lagu daerah ini akan diambil nilai praktek yaitu menyanyikan lagu daerah non unisono dengan gaya dan teknik yang benar. Disini guru juga mendiskusikan masalah-masalah yang dihadapi oleh siswa selama pelajaran berlangsung agar siswa bisa lebih baik lagi dalam pembelajaran musik Dalam penilaian juga ada nilai proses dimana guru menilai bagaimana perkembangan anak dari pertama diberi materi tentang lagu daerah. Latihan sebelum penilaian ini dilakukan oleh semua kelompok yang ada dalam kelas dan masing-masing siswa bisa memberikan saran kepada kelompok lain untuk melatih siswa mengutarakan pendapatnya. Setelah semua kelompok selesai melakukan latian yang dilakukan dengan mengulang lagu Gundul-Gundul Pacul tersebut, guru akan memulai melakukan penilaian akhir untuk materi lagu daerah yang dinyanyikan secara non unisono.

Kegiatan "mengkomunikasikan" dalam kegiatan pembelajaran sebagaimana disampaikan dalam Permendikbud Nomor 81a Tahun 2013, adalah menyampaikan hasil pengamatan, kesimpulan berdasarkan hasil analisis secara lisan, tertulis, atau media lainnya (Hosnan, 2014:75). Kegiatan mengkomunikasikan dilakukan dengan siswa mempresentasikan tugas 
yang sudah diberikan oleh guru. Tugas tersebut adalah tugas kelompok yang pada tahap ini dipresentasikan di depan kelas bersama dengan kelompok masing-masing siswa dan membawakan lagu daerah Gundul-Gundul Pacul dengan format vokal grup secara non unisono dengan aransemen 2 suara yang dibuat sendiri oleh masing-masing kelompok. Tugas untuk menyanyikan lagu daerah secara non unisono dapat melatih siswa untuk bisa bekerja sama dengan teman satu kelompoknya dan juga mengasah kreativitas siswa dalam hal seni vokal. Setelah siswa selesai mempresentasikan hasil pekerjaannya, siswa juga menampung masukan-masukan dari kelompok lain karena kelompok lain diberi kesempatan untuk memberi komentar, saran atau perbaikan mengenai apapun yang dipresentasikan rekannya, tugas guru adalah memberi penjelasan yang lebih kepada siswa di depan kelas. Selanjutnya kegiatan penutup meliputi guru bersamasama dengan siswa membuat rangkuman atau simpulan pelajaran, melakukan penilaian atau refleksi terhadap kegiatan yang sudah dilaksanakan secara konsisten dan terprogram, memberikan umpan balik terhadap proses dan hasil pembelajaran, merencanakan kegiatan tindak lanjut dan menyampaikan rencana pembelajaran pada pertemuan berikutnya.

Evaluasi secara umum dapat diartikan sebagai proses sistematis untuk menentukan nilai sesuatu (tujuan, kegiatan, keputusan, unjuk-kerja, proses, orang, objek, dan yang lain) berdasarkan kriteria tertentu melalui penilaian (Dimyati dan Mudjiono, 2013: 191). Evaluasi atau penilaian pembelajaran yang dilakukan oleh guru dibagi menjadi 3 aspek evaluasi, yaitu pengetahuan, keterampilan, dan sikap. Evaluasi tentang pengetahuan merupakan evaluasi yang dilakukan untuk menilai materi apa saja yang siswa dapat dari guru. Penilaian pengetahuan terbagi menjadi 2 yaitu tugas dan ulangan harian. Tugas didapatkan siswa setiap pertemuan, dan ulangan harian dijalani siswa pada akhir materi dan materi vokal terdiri dari 4 pertemuan. Pada pembelajaran musik, penilaian keterampilan hanya penilaian proses dan penilaian portofolio. Penilaian proses dilakukan selama pembelajaran musik berlangsung. Disini guru melihat perkembangan siswa dari pertemuan ke pertemuan apakah ada kemajuan atau tidak. Penilaian proses dilakukan dengan menilai penyajian vokal grup dari setiap kelompok yang telah dibuat pada pertemuan pertama. Tugas portofolio diberikan kepada siswa dengan memberi tugas siswa untuk menjelaskan materi mengenai vokal yang telah diberikan oleh guru seperti jenis-jenis lagu daerah, unsur notasi angka, dan teknik bernyanyi. Penilaian sikap berhubungan dengan bagaimana perilaku dan kedisiplinan siswa dalam mengikuti pembelajaran vokal. Penilaian sikap meliputi penilaian diri sendiri, penilaian antar teman, dan observasi.

\section{SIMPULAN}

1. Tahapan mengamati dilakukan siswa pada pertemuan kedua. Yang dilakukan siswa pada pertemuan kedua adalah siswa memperhatikan guru yang memberikan contoh teknik vokal yang baik melalui pemanasan dan menyanyikan lagu GundulGundul Pacul.

2. Tahapan menanya dilakukan dengan siswa dan guru melakukan tanya jawab mengenai materi yang diberikan oleh guru. Video dan contoh teknik vokal dari guru digunakan untuk merangsang munculnya pertanyaan atau pengetahuan baru dalam diri siswa.

3. Tahapan mengasosiasi dilakukan dengan pembagian kelompok yang telah dibuat oleh siswa terdiri dari 5-6 anak kemudian membahas tentang jenis lagu daerah, unsur notasi musik, dan teknik vokal. Pada pertemuan ketiga siswa mempresentasikannya didepan kelas. 
4. Yang keempat adalah mencoba yaitu membuat refleksi vokal pada pertemuan pertama setelah mengamati video tentang vokal grup. Pada pertemuan kedua siswa mencoba untuk menyanyikan lagu GundulGundul Pacul secara non unisono bersama dengan kelompoknya masing-masing yang diawali dengan pemanasan. Pada pertemuan ketiga dan keempat dilakukan untuk berlatih kembali dan mengambil penilaian.

5. Tahapan terakhir yaitu mengkomunikasikan hasil dari mencoba selama 4 pertemuan untuk penilaian yang akan dilakukan oleh

\section{REFERENCES}

Ali, Lukman dkk. 1995. Kamus Besar Bahasa Indonesia. Jakarta:Balai Pustaka.

Ali, Matius. 2010. Seni Musik Untuk SMP dan MTS Kelas VII. Jakarta: PT. Gelora Aksara Pratama.

Badudu J.S dan Zain, Sultan Mohammad. 1996. Kamus Umum Bahasa Indonesia. Jakarta: Pustaka Sinar Harapan.

Daryanto. 2014. Pendekatan Pembelajaran Saintifik Kurikulum 2013.Yogyakarta: Gava Media.

Depdiknas. 2001. Kamus Besar Bahasa Indonesia. Jakarta: Balai Pustaka.

Dimyati dan Mudjiono. 2013. Belajar dan Pembelajaran. Jakarta: Rineka Cipta.

Fadlillah, M. (2014). Implementasi Kurikulum $2013 \quad$ Dalam Pembelajaran SD/MI, SMP/MTs, \& SMA/MA. Yogyakarta: Ar-Ruzz Media.
Fauzziyah, Fikri. 2012. Hubungan Penerapan Apersepsi oleh Guru Terhadap Motivasi Belajar Siswa pada Mata Pelajaran Sosiologi di SMA N 1 Dukupuntang Kabupaten Cirebon. Skripsi. IAIN Syekh Nurjati, Cirebon.

Hamalik, Oemar. 2010. Kurikulum dan Pembelajaran. Jakarta: PT. Bumi Aksara.

Hosnan, M. (2014). Pendekatan Saintifik dan Kontekstual dalam Pembelajaran Abad 21 Kunci Sukses Implementasi Kurikulum 2013. Jakarta: Ghalia Indonesia.

Jamalus. 1988. Pengajaran Musik Melalui Pengalaman Musik. Jakarta:Proyek Pengadaan Buku Sekolah Bagi Guru.

Kurniasih, Imas dan Sani Berlin. 2014. Implementari Kurikulum 2013 : Konsep \& Penerapan. Surabaya: Kata Pena.

Martin, David Jerner. 2006. Elementary Science Methods: A Constructivist Approach, Fourth Edition. USA: Thomson Wadsworth.

Munib, Achmad. 2012. Pengantar Ilmu Pendidikan. Semarang: UNNES Press.

Ottman, Robert W. 1962. Elementari Harmony Theori and Practice. USA : Prentice Hall

Rasyid, Fatur. 2010. Cerdaskan Anakmu Dengan Musik. Jogjakarta: Diva Press.

Safrina, Rien, Pendidikan Seni Musik. Jakarta: Depdikbud

Sagala, Syaiful. 2013. Konsep dan Makna Pembelajaran. Bandung: Alfabeta. 
Sanjaya, Wina. 2007. Strategi Pembelajaran Berorientasi Standar Pendidikan. Jakarta: Kencana.

Sani, Ridwan Abdullah. 2014. Pembelajaran Saintifik untuk Implementasi Kurikulum 2013. Jakarta: Bumi Aksara.

Setianto, Damar Anggit. 2014. Penerapan Pendekatan Saintifik pada Pembelajaran Musik Ansambel Pada Siswa Kelas VIII E di SMP Negeri 3 Ungaran. Skripsi. UNNES, Semarang.

Sugiyono. 2013. Metode Penelitian Pendidikan. Bandung: Alfabeta.

Suharto, S. (2011). PENGEMBANGAN MATERI DAN KEGIATAN PEMBELAJARANNYA DALAM KURIKULUM TINGKAT SATUAN PENDIDIKAN BIDANG SENI MUSIK. Harmonia: Journal Of Arts Research And Education, 8(3). doi:http://dx.doi.org/10.15294/har monia.v8i3.780

Suharto, S.(1991). Bayangan Nada sebagai Materi bagi Pembelajar Pemula. Media, 18(2)

Sukarman, Herry. 2003. Dasar- dasar Dikdaktik\&Pembelajaran. Jakarta: Direktorat Kependidikan.

Sumaryanto, Totok. 2005. Efektivitas Penggunaan Metode Solfegio untuk
Pembelajaran Keterampilan Bermain Musik di Sekolah Dasar. Harmonia. Volume 6, Nomor 2. Semarang: Sendratasi UNNES.

Sumaryanto, Totok. 2014. Metodologi Penelitian Kualitatif Untuk Pendidikan Seni. Semarang: Sendratasik UNNES.

TIM MKDK, IKIP Semarang. 1996. Belajar dan Pembelajaran. Depdikbud. IKIP Semarang.

Tim Penyusun Kamus Pusat Bahasa. 2001. Kamus Besar Bahasa Indonesia. Jakarta: Balai Pustaka.

Utami, Ika Budhi. 2015.Implementasi Pendekatan Saintifik Dalam Kurikulum 2013 Pada Siswa Kelas II SDN Prembulan, Pandowan, Galur, Kulon Progo. Skripsi. UNY, Yogyakarta.

Ganap, V. (2011). Pengaruh Portugis pada Musik Keroncong (Portuguese Influence to Kroncong Music). Harmonia: Journal Of Arts Research And Education, 7(2). doi:http://dx.doi.org/10.15294/har monia.v7i2.753

Wulandari, Eky Olivia. 2015. Peningkatan Motivasi dan Hasil Belajar Teknik Vokal dalam Bernyanyi melalui Penerapan Metode Tutor Sebaya pada Siswa Kelas VII D di SMP Negeri 5 Batang. Skripsi. UNNES, Semarang. 